\title{
Militancy and violence in West Africa: reflecting on radicalisation, comparing contexts and evaluating effectiveness of preventive policies
}

\section{'Funmi Olonisakin, Ismail Rashid and James Gow}

By 2000, 'radicalisation' had become a major global issue. Although '9/11' was still a year away, the American Embassies in East Africa had been bombed in 1998 and violent conflicts simmered in many parts of the world. At just about the same time, bitter civil wars, resource-centred conflicts and intra-

ethnic strife raged in West Africa. Against the background of research being undertaken at King's College London, ${ }^{1}$ the mutually reinforcing links between 'radicalisation' and 'violence' (potentially sensitive terms, discussed below) in West Africa became clearlyobvious and a successful application to investigate this was submitted to the UK Economic and Social Research Council (ESRC).2 This Special Issue contains articles emerging from that work, with a set of country studies complemented by overarching synthetic analysis.

\footnotetext{
'Funmi Olonisakin is Director of the African Leadership Centre and Conflict, Security and Development Group, King's College London. She is Research Associate with the Department of Political Science, University of Pretoria. She previously worked in the Office of the UN Special Representative of the Secretary-General on Children and Armed Conflict.

Ismail Rashid, a Sierra Leonean, is a Professor of History at Vassar College. He received his PhD in African History from McGill University. He is currently completing an anthology (with Sylvia Macaulay) tentatively titled, The 'Province of Freedom' at Fifty: Paradoxes of History and Memory in Post-colonial Sierra Leone (forthcoming 2013).

James Gow is Professor of International Peace and Security and Co-Director of the War Crimes Research Group, King's College London. Current research projects include: Shifting Securities; and Visual Material and War Crimes Prosecutions. His latest book is titled War and War Crimes: The Military, Legitimacy and Success in Armed Conflict (Hurst, 2013).
} 


\section{Background}

Several background considerations prompted our interest in 'radicalisation' and 'violence' in West Africa. First, the decades of conflicts and instability in the region have made it vulnerable to various forms of cross-border instability. Indeed, there emerged what has been described as 'mobile dissident forces' operating across countries in the region. Second, the region was fast becoming important in global resource politics, with the United States confirming that a quarter of its oil consumption will be coming from the region by 2015. Indeed, the entire Gulf of Guinea is of enormous strategic interest in global energy politics. Third, natural resources in the region were already becoming contentious, with alleged links with global terrorism, as in the case of uranium in the Niger Republic and diamonds in Sierra Leone. The former Liberian President, Charles Taylor, who was tried by the Special Court of Sierra Leone at The Hague and found guilty of crimes against humanity, had allegedly sold Sierra Leone's diamonds to al-Qaeda. Lastly, 'radicalisation' and 'violence' also underlined the crucial issue of youth vulnerability and exclusion, rooted in the phenomenon of the youth bulge, whose prevalence in West Africa remains an issue of global importance. ${ }^{3}$

So far, the terms 'radicalisation' and 'violence' have appeared in quotation marks. This is a form of distancing to show that these terms can be the subject of multiple sensitivities. Indeed, the discourse surrounding the ESRC 'Radicalisation' and 'Violence' Programme that funded the research was ample evidence of this contestation. Many academics, mainly anthropologists, objected to the framing of the Programme, and this led to its formal enunciation with distancing quotation marks around those particular words. Similar sensitivities prompted us initially to frame our project in terms of 'militancy', where the combined elements of 'radicalisation' and 'violence' are more likely to be connected, even though there is still no necessary implication that 'militancy' entails violence. However, as we developed the project after gaining funding, while recognising the delicacy of the terms and that they could entail assumptions that not everyone would accept, we took the decision that there would be no single or fixed definition associated with these key terms. Researchers would both use terms as they are related to the specific contexts of their 
investigations and also always explore any potential sensitivities over them (and any other terms) with participants at the start of research sessions. As discussed in one of the articles, ${ }^{4}$ this pragmatic approach was in some way validated, as no concerns emerged anywhere in the research as it was conducted.

From the outset, one major consideration guided the research. This was that the wider instability in West Africa has the tendency to obscure radicalisation and violence in the region. Furthermore, we felt that the sporadic nature of some of the conflicts emanating from radicalisation, their relatively short duration and the ease with which their root causes can be subsumed under other wider security challenges have all given the impression that this category of violence is often 'localised' and, as a result, not likely to have consequences or wider ramifications. Consequently, beyond the broad identification of radicalisation as a possible cause of political instability, not much attention was given initially to how radicalisation and violence in West Africa can have wider ramifications. However, as the research drew to an end the Boko Haram phenomenon began in Nigeria and within a few years the conflict in Mali escalated-both demonstrating the ways in which radicalisation and violence can have wider ramifications. The article by Gow, Olonisakin and Dijxhoorn discusses this further.

\section{Objectives}

A small number of the objectives identified at the beginning of the research underwent minor changes during the course of the research. These became necessary in order to bring clarity to the research. To a very large extent, we were able to meet all of the targeted objectives in the course of the project. Below are the initial objectives and the nuances with which they were addressed.

- To trace both the root causes of Muslim 'radicalisation' in West Africa and how the nature and manifestations of it have changed over the years;

This particular objective, which emphasised the importance of foregrounding the particular history of Islam in the different contexts, was slightly expanded to account for the role of Christianity both as another form of radicalisation and as a source or influence (through rivalry and competition) on Islamic radicalisation in West Africa.

- To investigate the doctrine(s) espoused by radical groups in the region and inquire whether the source of this (these) doctrine(s) is the Qur'an or the Hadith; 
Every country study identified the main radical Islamic groups and the doctrine espoused, but in a situation where new groups are constantly emerging and where these groups are also somewhat confused about their doctrine, it is practically impossible to catch up with new emergence. For example, just as the research was completed a new group emerged in Nigeria with doctrines that were clearly different from any of the previously known groups. ${ }^{5}$

- To ascertain the recruitment base(s) of these groups and the local, national and (where possible) sub-regional issues exploited in the process of recruitment;

All of the baseline studies conducted in the four countries identified the recruitment bases of the main groups discussed. We were also able to identify cross-border issues that are vital to the recruitment process. This was achieved through semi-structured interviews and focus group discussions as further discussed below. The employment of local researchers to assist in the process also assisted in unravelling some of the complex web in the recruitment process of these groups. Because of their understanding of local realities, these local researchers were able to access local sources that would have been difficult for outside researchers.

- To ascertain the extent to which the problem of Muslim radicalisation has spread (or might spread) from one country to another in the region;

Every country study undertook an assessment of the nature of Islamic radicalisation and the potential for this to spread across the country and beyond that country's borders. The common trend as further discussed below was the tendency for radicalisation to be tied to specific local causes and issues, which at the time of the research did not have regional roots or connections although some cross-regional connections have become apparent with the conflict in Mali.

- To determine the effectiveness of the measures that the countries under investigation have put in place to meet the challenges of a possible crisis emanating from violent radicalisation that is connected to the expression of faith;

In all of the countries the research teams were able to observe the patterns and forms of government responses to militancy and violence. In all cases, the research team found little evidence of concrete measures put in place by governments to address violent radicalisation. Where some evidence existed, the effectiveness of such policies was questionable. In a way, 
circumstances (even if admittedly unpleasant) assisted the research team in realising this objective. This is because research team members were, on one occasion in Nigeria, present during one of the violent outbreaks associated with radicalisation. This thus afforded the team a first-hand opportunity to assess responses to radical violence.

- To investigate the likelihood of a crisis emanating from faith-induced radicalisation in West Africa having global ramifications, especially against the background of the region's enormous natural resource endowment;

The research was able to achieve this through interviews and focus group discussions. Against the background of previous research undertaken by the team, the research was able to identify key areas where the possibility of violence over West Africa's natural resources can influence global production.

- To establish the extent to which national boundaries can impact on the above questions and, in particular, how easily weapons can move across borders in the event of conflicts arising out of radicalisation.

This was achieved in part through interviews and discussions with the Immigration Service and the Police in the region. In the case of Liberia, the Small Arms Unit of the United Nations provided some assistance by pointing us towards relevant sources that revealed the extent of the problem.

\section{Methods}

This project was undertaken in four phases. The initial phase of research produced what we labelled as 'baseline studies', establishing existing knowledge, understanding and interpretation of religion, radicalisation and violence in the countries under investigation. Because of the timeframes involved in the project, consultant specialists were recruited to produce three of the initial baseline studies, while a project research associate drafted the other. At the end of this phase, the draft baseline studies were reviewed and evaluated by the project team, as well as by peer reviewers, and discussed at a Project Meeting in June 2008. The second phase involved both supplementary work on the baseline studies and the outlining of propositions to be tested in the third phase of research. The third phase of research involved focus group research in each of the countries, supplemented, as necessary, by semi-structured interviews with individuals with particular expertise or occupying 
positions of relevance. As far as relevant and possible, focus groups were conducted to reflect regional differentiation and societal stratification: general focus group sessions were held with mixed ethnicity, religion and gender groups; clustered focus group sessions were organised along ethnicity, religious, gender and generational lines, or involving a mixture of these factors. The final phase of research involved integration of the different parts of the research, including critical evaluation by the project team. The relevant panel of the Research Ethics sub-committee subjected the proposed research to considerable scrutiny, with particular regard to the concerns that had surrounded the ESRC Radicalisation and Violence Programme, as a whole.

These focus group sessions posed a variety of challenges for researchers in the field. In some countries, recruitment of participants for the focus groups was difficult and sometimes sessions had to be cancelled, but the majority were conducted successfully. While sessions were generally conducted in a positive and harmonious atmosphere, despite the issues under discussion, on two occasions, tension was great and some participants became intemperate, requiring temporary suspension of sessions and conciliation by the session facilitator. There were particular problems arranging sessions in Kano, in Nigeria, where there has been religious violence; sensitivities were great in this case, and caution had to be used. This was the sharpest of several instances in which participants would not agree to electronic recording of sessions and were reluctant to sign ethical consent forms. For the most part, however, participants in sessions were content with both recording and signing consent forms. Nonetheless, this must be noted as an important sensitivity in the research.

\section{The articles}

Four of the six articles in this special issue illuminate broad trends in the processes of Islamic radicalisation and militancy in West Africa, in four Anglophone countries. Each used the common methodology described above and each follows that methodology in presenting its findings. None the less, Nigeria clearly stands apart from the other threeSierra Leone, Ghana and Liberia - in the quest to understand the complexities of religious radicalisation and violence in West Africa because of the recent emergence of the militant group Ahl as-sunnah wa al-Jama'ah ala Minhaj as-Salaf, widely known as the Boko Haram. Boko Haram has repeatedly used terror and violence against federal and local government security agencies and civilians to press home its desire to transform Nigeria into an Islamic 
state. Alao's article locates the emergence, aims and actions of Boko Haram within an historical perspective. The article suggests that Boko Haram reflects a new phase and manifestation of Islamic radicalisation in Nigeria with multidimensional roots. Alao argues that the violent activities of Boko Haram reflect the various contradictions in the Nigerian State, and he posits that factors beyond the oft-cited socio-economic ones account for Islamic radicalisation and associated violence in Nigeria.

In contrast to Nigeria, Ghana, Liberia and Sierra Leone indicate zones of intensifying Islamic piety where the religion has not been highly politicised or violently mobilised to achieve political ends even if the regional socio-economic challenges are similar. Nevertheless, the historic as well as contemporary links between Northern Nigeria, where Boko Haram has been active, and Northern Ghana, where the country's Muslim population is concentrated, has caused concern. Kwesi Aning and Mustapha Abdallah in their study of Ghana, however, stress that the doctrinal differences and methods of proselytisation are the main catalysts in the radicalisation and violence amongst the three major religious sects-Al-tijaniyya Movement, Ahlussunna Waljama'a and Ahmadiyya Movement_-in Ghana.

Like Northern Ghana, post-conflict Sierra Leone generated international concerns that it might become a haven for religiously-inspired violence because of the implication of al-Qaeda becoming involved in the circulation of conflict diamonds. Kevin O'Brien and Ismail Rashid point out that these concerns are largely unfounded. Prolonged economic impoverishment and foreign religious influences, especially from Saudi Arabia and Iran, they suggest, are encouraging the reinvigoration of Islam in post-war Sierra Leone. Though this trend has produced more purist strains of Islam in different parts the country, O'Brien and Rashid argue that there is no evidence that Sierra Leonean Muslim groups are actively engaged in large-scale religiously-inspired extremism and violence.

The article by Thomas Jaye and Abiodun Alao discusses the impact of Islam on the process of armed conflict in Liberia. The authors argue that Islamic radicalisation played a role in the manifestation of the conflict and served as a tool to advance ethnic interests. In particular, in this article the notion of radicalisation is nuanced given the contentious and different manifestations of radicalisation in Liberia when compared to the other countries. As such, Jaye and Alao discuss 'triggers of radicalisation' and the ways in which Islamic radicalisation is manifested in identity-based interests which link ethnicity and religion. 
The fifth article in this special issue by Olawale Ismail provides an overview of emerging trends in the process of radicalisation and violent extremism in West Africa and discusses the implications of this for regional and international security. Ismail argues that concentrating attention on violent extremism alone without interrogating its structural underpinnings — and by so doing slowing the momentum of radicalisation-compounds the security situation in Africa. Building on the four country case studies, Ismail maps the drivers of radicalisation in West Africa and attempts to chart the pathway from radicalisation to violent extremism while assessing the implications of all this for security in Africa and beyond.

The concluding article to this Special Issue by Gow, Olonisakin and Dijxhoorn reflects on recent evolutions in radicalisation and violence in the region, the role of military approaches to international security and what these mean for local perceptions about radicalisation and violence. They argue that a more 'nuanced and variegated understanding' is required in order to effectively address issues of militancy and violence in West Africa. As such, it is important to acknowledge the need for an internationalised and military approach — and in this regard they discuss the 2012 and beyond crisis in Mali and the Sahel—as well as the underpinning conditions for radicalisation. In this latter regard, and on the basis of the focus group research conducted across the four countries, the article interrogates the extent to which local conditions including socio-economic factors as well as perceptions of the role of colonial history serve as underlying factors in radicalisation. The authors argue for the need to take these into account as part of preventive mechanisms.

Lastly, we should underscore that the articles in this collection present original empirical data and analysis, derived from the focus group discussions undertaken as a core part of the ESRC-sponsored research referred to at the start of this introductory piece. ${ }^{6}$

\section{Endnotes}

1. For example, Dr Olonisakin was researching into the civil wars in the region and was completing her book on the politics of United Nations involvement in the Sierra Leone war, while Dr Alao was looking at the politics of natural resource conflicts in the region and was also completing a book on the subject. The Conflict Security and Development Group (CSDG), King's College London, was awarded a grant from the UK Department for International Development (DfID) to undertake a research project on youth vulnerability and exclusion in West Africa, with Dr Olonisakin as principal investigator.

2. 'Militancy and Violence in West Africa: Reflecting on Radicalisation, Comparing Contexts, and Evaluating Effectiveness of Preventive Policies'. Dr F. Olonisakin and Prof A.J.W. Gow. ESRC Award No. RES-181-25-0024.

3. We have just completed a major research project on Youth Vulnerability and Exclusion in West Africa (mentioned 
in endnote 1 above). This study includes Nigeria and Liberia.

4. See the concluding article by Gow, Olonisakin and Dijxhoorn.

5. This group is known as the Kala Kato or Qur'aniyyun. It emerged in Zaria, Northern Nigeria. Unlike other radical Islamic groups that recognise three sources of Islamic jurisprudence, namely the Qur'an, Hadiths/Sunnah and Ijma (consensus of Islamic scholars), this group claims that it only recognises the Qur'an.

6. In addition to the articles in this Special Issue, extended, more detailed and extensive country studies, incorporating the baseline historical analyses that were part of the methodology for the research presented here, will be presented in a forthcoming book: Gow et al., Militancy and Violence in West Africa.

\section{References}

Alao, Abiodun, 2007. Natural Resources and Conflict in Africa:

The Tragedy of Endowment. University of Rochester Press, Rochester.

Gow, James, 'Funmi Olonisakin and Ernst Dijxhoorn (eds.), forthcoming 2013. Militancy and Violence in West Africa: Religion, Politics and Radicalisation. Routledge, London. Olonisakin, 'Funmi, 2008. Peacekeeping in Sierra Leone: The Story of UNAMSIL. Lynne Reinner, Boulder. 